\title{
Transformation of Corporal Communication between Pilot and Machine in Russian Literature of the Early $2^{\text {th }}$ Century
}

\author{
Tatiana A. Zagidulina* \\ Krasnoyarsk State Pedagogical University \\ named after $V$. . P. Astafyev \\ 89 A. Lebedeva Str., Krasnoyarsk, 660049, Russia
}

Received 06.02.2016, received in revised form 15.03.2016, accepted 28.04.2016

The research is devoted to the problem of transformation in corporal communication between pilot and machine in Russian literature of the 1910-20s. The purpose of this research is to compare conceptual anthropomorphous and technical metaphors of classical and non-classical poetics. This analysis is based on the texts written in the 1910-1920-s and devoted to aviation; the theme selection is explained by the high distinctiveness of the text in the context of the chosen period. The author researches the development of two myths: the future-oriented, futuristic myth, where the human merges with the machine and assimilates with the mechanism; and the past-oriented myth where the assimilation of the machine to a living creature comes to the fore. The second myth is relevant for classic literature (A. Blok, A. Kuprin, L. Andreev and others). This myth perfectly fits the pre-Soviet, Christian worldview, where soul is more important than mind and Christian images of the space structure (sacred top - sublunar bottom). The futuristic myth created by V. Mayakovsky, V. Khodasevich, V. Kamensky and others, is aimed at desacralization of heaven, highlighting the idea of merge of human and machine and even the idea of replacing human with the machine.

Therefore, one may speak of two mythologies as two different worldviews, which appear in literature and culture in such an important and crucial period for Russian culture as the 1910-1920-s.

Keywords: myth, zoomorphic metaphor, anthropomorphous metaphor, corporal communication, Soviet literature, social realism.

DOI: 10.17516/1997-1370-2016-9-5-1081-1088.

Research area: philology.

The turn of the $19^{\text {th }}$ and $20^{\text {th }}$ centuries was marked with a great scientific and technical leap. Everything that had been fantasy became real. Among the new achievements there was flying, the opportunity to rise into the sky riding a machine heavier than air. Naturally, the fact caused a stormy reaction of the men of letters. This research studies the transformation of ideas of the corporal relations of the aviator and the flying machine, as well as the changes in presenting the sky in classical and non-classical artistic paradigms. The texts selected for analysis are works by A. Kuprin, L. Andreev, V. Mayakovsky, I. Severyanin, A. Blok. V. Khodasevich.

(C) Siberian Federal University. All rights reserved

* Corresponding author E-mail address: zagi9@rambler.ru 
There are several milestone texts that are of special importance. Those are sketch "Bird Men" by A. Kuprin (1917), poems "Give motor" (1925) and "Don't Your Shoulder Blades Itch?" by V. Mayakovsky, and story "Flight" by Leonid Andreev (1913). These texts are the most representative as myth bearing texts. A. Kuprin, A. Blok, L. Andreev are regarded as representatives of the classical artistic paradigm, and V. Mayakovsky and I. Severyanin as those of the non-classical one.

The corporal connections manifest themselves, first of all, through metaphor. It is important that in the cognitive process a metaphor is rather an object for interpretation than understanding, as noticed by the author of the introduction article "Metaphor and Discourse" to the "Metaphor Theory" collection by N. Arutiunov. The researcher suggests that the "decomposition of the image into symbolic elements provides an opportunity for interpretation" (Arutiunova 1990, 23). Moreover, metaphor is directly connected with myth just like mythological and linguistic thinking are connected to each other; it was remarked by E. Cassirer in "Metaphor Force" (Cassirer 1990, 33), so it is possible and it is necessary to reveal the myths created by means of metaphor.

In the texts of the selected epoch metaphor performs an epistemological function, i.e. cognition of the unknown through the known. Metaphor "is committed to create such an image of an object that would reveal its covert core" (Arutiunova 1990, 24), and it is the research of perception of such "covert core" by the text author that is the key to understanding the cognitive processes typical of the epoch as a whole. We speak of the cognitive processes connected with the perception of a physical flight of a human on a machine heavier than air, as well as interaction of human and the machine. Metaphor is directly connected to myth. This way, metaphor is the thing that shapes up the world outlook.

The myth of the approach/merge of the sacral sky and mundane terrain manifests itself in the texts of this period to great extent. The reason is that the 1910-20-s were the beginning of popularization of aviation. The flights of Wright brothers and other father founders, no doubt, drew a lot of public interest, but it was back in the early $20^{\text {th }}$ century that the popularity of aviation achieved such a scale. Starting from 1910, socalled Weeks of Aeronautics were held in Saint Petersburg; as a result, lots of artistic texts presenting the nature of flying machines, the relationships between the aviator, the machine and the space were born. The first attempts to comprehend these relationships in the artistic way were made.

The main character of story "Flight" by L. Andreev has a real prototype, pilot Lev Matsievich, who died in the first Russian air crash in 1910. However, the ideas expressed by the main character, bear great archetypical load. The sky acts as the other world, the alien space of unlimited freedom: "There passed a shortest instant since Yuri Mikhailovich had rose from the ground, but he was already in the other world, in the other environment, so light and endless" (Andreev 1982, 387). It emphasizes the impossibility of physical existence of a human in this alien space; the consciousness of the observer, perceiving flights as something extraordinary, is not yet ready to see a human body in the air, so it makes real physical life there impossible. It is also proven by the fact that the luck of the main character and the absence of any physical harm he may have had are seen as something surprising: "twenty eight times - just as many as years he had lived he had risen in the air and yet was alive, he had neither died nor broken his legs and arms like others" (Andreev 1982, 386). The lucky 
physical being of the main character in the air environment is presented as a "ridiculous and small experience": such diminutive characteristic highlights the impossibility of full and sound physical existence of a pilot in the sky once again.

Poem “Aviator” by A. Blok (1910-1912) is dedicated to the same event as the story by L. Andreev: the death of Lev Matsievich. In the poem one can also clearly read the impossibility of sound existence of the pilot body in the environment of the skies and the uselessness of flight as such: "Why did you fly to the sky, courageous one, / for you first and last time? / Did you do it to make a venal socialite lady / Look at you once with her violet eyes?" (Blok 1962, 31). Just like in the story by L. Andreev, in the poem by A.Blok the sky is the essence of freedom. Compare: A. Blok: "The flier is finally set free/ As he swings two of his blades..." and L. Andreev: "no one down there knew how much space there was, how wide were the arced gate and how endless the blue straits were, how queenly magnificent, wide and free was the sky archipelago" (Andreev 1982, 389). But in L. Andreev's story freedom as an attribute of space intercrosses with freedom as an attribute of will: "There were no beaten paths here, and in its unlimited run so divinely free did the will create itself, and did it wing itself with the wings so wide (Andreev 1982, 389). The attribute "divinely" underlines the sacredness of the sky environment.

Both L. Andreev and A. Blok compare air and water elements, describing the unknown through the known. A. Blok: "The flier is finally set free, / Having swung its two blades, / Just like a sea beast into the water / He slipped into the air streams" (Blok 1962, 31); L. Andreev: "and from time to time it seemed that the flier was sliding and seeking for a path in between the clouds, just like a sailor is looking for his way between the islands" (Andreev 1982, 392).
In both texts there is an obvious motive of withdrawal/escape from one's self and body through integration into the sky, which leads to physical death. A. Blok speaks of this moment as of "self-abandonment"; it is worthwhile noticing the following lines: "Of did you experience / The fatal amusement of self-abandonment, / Did you long for fall that badly / That you chose to stop the blades yourself?" (Blok 1962, 31). Here the fall is not a coincidental event, the fall is a result of the released will and spirit, a specific ascension opposed to the physical fall of the body, which is explicitly described as ugly: "Too late: on the meadow grass / There lies a crumpled arc of wing... / And in between the machine wires / There is an arm that is deader than its lever" (Blok 1962, 31). The physical body found its last resort on the ground, having merged with the machine body, physically just as dead. The body of the machine is dead as that of the pilot; if in the beginning of the poem the author uses some zoomorphic metaphors "Having swung its two blades, / Just like a sea beast into the water..." "And the beast with blades now quiet / Is hung, bent in a scary angle..." and personifications like "singing blades", "moving copper" (active voice use), "the propeller keeps on singing", but the last description of the airplane is different due to its emphasized naturalism: "a crumpled arc of wing", “... and in between the machine wires...”. During flight it is not only the human spirit that remains in the sky, but also the spirit of the machine; only fragments of the airplane and a dead human body fall on the ground.

L. Andreev: "Yuri Mikhailovich opened his eyes and looked down, on the terrain. Raising his eyes from the smoking terrain, he thought: 'This is when by happy dream came true; here I am in the sacred shelter of mine, walking through my beautiful chambers, and there is no one here with me, no one but light alone"' (Andreev 1982, 393). The main character found his true home, which 
is the sky, the "sacred", but the sacredness here stands for freedom: he frees his spirit from the flesh and dies, as though deliberately ("No! I shall not come back to earth"). The catharsis motive is directly associated with the element of fire the main character surrenders to before the ultimate release of the soul: "He had long forgotten of himself; he had long forgotten who he was and what brought him to the air, and now he was a star again, a clot of furious fire coursing through the space, spitting back the sparks and blue flames. And suddenly he felt that his hair burned in fiery curls, and stream to the ground, waving; and suddenly he realized that it was the direct path from one endlessness to the other, he could clearly himself, rushing from this eternity to the other one, where the gate of his sacred secret shelter are open, waiting. 'How can I come back to the ground?' - sang his soul in blissful oblivion" (Andreev 1982, 393). The pilot loses his physical self; it is not himself, but his soul that becomes capable of thinking.

Another poem, representative of the sacredness of the sky space motive, is "Aviator" by V. Khodasevich. As its antagonist flies through the sky, he has no body, and the author calls him "the celestial - the hero - the man", but in the terrain space he is an absolutely physical creature which is emphasized with the diminutive description: "Ah, let yourself fall in large zigzags, / Fall on the ground, breaking your spine, / To the bleachers coloured with flags, / Where the people, the orchestra and the cafes are...", while sky is described as: "And the piled up tiers around him / Only clouds - only clouds - only clouds" (Khodasevich 1992, 152).

Mentioning the myth of catharsis, the motive of releasing the soul through death, we cannot but remark the unfinished novel "Happy Moscow" by A. Platonov (first chapters published in 1934), where a similar episode takes place. The heroine catches on fire in the air, but it does not end in purification or death, no transition happens. The pattern of purification through fire and release of the spirit loses turns irrelevant in the 1930-s. "Moskva began rocking, yet invisible behind the fog, lonely and free. Then she took out a cigarette and matches, wishing to light it for a smoke, but the fire went off; then Moskva hunkered down $<\ldots>$ and exploded all matches in the box at once, and in an instant the fire $<\ldots>$ caught the flammable lacquer the silk straps had been damped with $\langle\ldots>$ the straps were burned in a second, they just flared and crumbled to dust, and where did the sheaths go..." (Platonov 2010, 34), "For a while all newspapers and magazines wrote of the happy and young courage of Moskva Chestnova; even abroad the press described her jump with a burning parachute in all details $<\ldots>$, but then it was over, and Moskva herself did not even realize her fame and what it was" (Platonov 2010, 34). Nothing changed in Moskva's consciousness, despite the fire she felt and the fire she went through; probably, in the years the novel was written the myth worked "the other way round", and the heroics of purification through death was already irrelevant.

The 1920-s were marked with the transition from zoomorphic metaphors and mechanism personifications: it was the time when the tendency to the physical merge of man and machine appeared, and it was connected, inter alia, with the pre-requisites of social realism, where the human body was thought of as a mechanism or similar to a machine (or a part of the mechanism). Poems by V.V. Mayakovsky are especially representative from this point of view. In "Pilot's Mockery" (1923) we read: "Be aerowinged!". It is the call to merge with the aeroplane, get its wings, take possession of them. But the reverse metaphors still remain used: the personification of the machine, prescribing it some living body elements: "And the core / Is the heart. / The heart is the motor / To leap / Brisker 
than wind" ("Give Motor", 1925) and zoological comparisons of the mechanism details: "See sparrows, / see them / using motors to glide". The tendency for mechanization of human body is enforced: "Don't you want from beneath / Your old blouse / Where the hump / used to be, / for a pair of wings / to wing themselves out / throwing off / the load/ of the anchor shirts?" 1923).

The tendency for desacralization of the sky environment appears; it leads to the changes in perceiving the figure of the aviator from a helpless and even ridiculous man in the sky to an almost divine creature, a god-man or even a man who is higher than god: "It's stuffy, / but skies are / so vast - / abyss! / I'd fly to / the gods' settlement! / I'd give that / Zebaoth / from housing unit / and order / for ejectment!" (Mayakovsky 1939, 436). The poet lays his hopes on the transformation of the human body, but not to turn it into a mechanism, but to assimilate it with the living creature, a bird: "But ... people a wingless /nation. / People / were based / on a lame plan: / just a back / and a fat lot of good. / Buying / an airplane / is the only / thing you do. / And there will grow / the tail, / the feathers, / the wings. / Sharpen / your chest / for the flight" (Mayakovsky 1939, 436). At this stage these ideas compete with the idea of the human body mechanization: "Tomorrow's, / aftertomorrow's / humankind, / you / invincible / steelarmed class of mine" (Mayakovsky 1939, 59). In the non-classical texts written by V. Mayakovsky the myth of purification and release of the soul from the body is transformed; now a man can be free together with the body, but the body needs transformation and some new elements. The space is also changed: from the sacral medium where physical existence of a man is impossible, to the other medium where a man is supposed to be, which enriches and widens the activity field for the man.

The tendency for desacralization manifests itself not only in poetic, but also in prosaic works of literature. In the short story "They're Flying" by V. Kataev the action takes place in two worlds: real and oneiric. In the real world Ivan Ivanovich, who is obviously not a Communist, exclaims: "And where is such a law that would permit Communists <..> to fly in the air?" (Kataev 2006, 46); oneiric is just as unfriendly to the imagination of Ivan Ivanovich, and the Communists who fly aeroplanes in his dreams, shout out to him: "We can see everything from above!", and this phrase allusively returns the reader to the fixed phrase "God sees and knows all things". In the consciousness of Ivan Ivanovich the sky remains sacral (which is also proven by how the pilots drop Easter eggs from the sky in his dreams). Ivan Ivanovich is a man from the past; that is why an aeroplane for him is a part of the past picture of the world, and aeroplane has no original meaning of its own, it is equaled to something living. The deification of aviators, the sacred character of the sky environment and impossibility to think of an aeroplane as of an inanimate nature object are all attributes of a myth typical of classical poetics; however, in this text the myth is turned upside down, reproduced through a character who looks into the past. Ivan Ivanovich is opposed to another, younger character, and the Communists. Those are all the bearers of a different, futuristic myth. To this or that extent, both myth work in the text, and the bearer of the negative one is Ivan Ivanovich; that is him who does not accept the desacralization of the sky through the presence of machines and people there. The bearer of the positive, futuristic myth is his young interlocutor, his son Kolya.

The classical poetics assumes the sacral character of the sky (L. Andreev, A. Blok, A. Kuprin), the unreachability of the sky, while the non-classical one (V. Khodasevich, V. Kamensky, V. Mayakovsky) deny the superiority of gods in the sky and proclaim the anthropocentric space. 
The man may physically, corporally exist in the air, it is not strange to him anymore.

One of the key images of the epoch is the motor-heart; this image witnesses the development of a new, partially technocratic, picture of the world. On one hand the engine is the heart of a machine; on the other, the heart of the human is an engine. Such merge of human and machine is deeply symbolic. Besides, it is one of the distinctive features of social realism with its aspiration for mechanization of the human body.

Therefore, transformation of physical relations between the man and the machine is caused by the transformation of the social myth of aviation. If in the 1910-s it was typical to perceive the sky as a sacral space, which is, consequently, unthinkable for a man to be, then in the 1920-s it is thought of a different one, suitable for man and unrealizable without him ${ }^{1}$. We may also trace this transformation on the basis of the texts presented in the present research which reflect the motives of this or that stage in the development of machine and man body representation in the sky. It means that the physical connections also change: in the 1910-s (A. Blok, V. Khodasevich, L. Andreev) a machine was something strange though perceived as an animate nature object; in the 1920-s (V. Mayakovsky, V. Kamensky) a man merges with the machine; it is not strange neither to him nor the sky, it does not bear any danger because now it is of the same nature with the man. The text by V. Kataev is especially remarkable for reflecting both tendencies at a time.

\footnotetext{
Данное разделение актуально только для литературы 10-х-20-х годов, 30-е дают уже иное представление о теле человека в небесном пространстве, показателен в этом смысле текст А. Платонова, отрывок из которого приведен выше.
}

\section{References}

Arutiunova N. D. Metaphor and discourse. The theory of metaphor. Collection, Moscow, 1990. pp. 23-24.

Arutunova N. Metaphora i diskurs. Teorija metaphory. Sbornik. Moskva. 1990. S.23-24.

Andreev L. Flight. Favourites. Moskow. 1982. P. 386 - 394.

Andreev L. Polet. Izbrannoe. Moskva. 1982. S. 386 - 394.

Blok A. A pilot. Collected works in 8 volumes, Vol. 3, 1962. p. 31.

Blok A. Aviator. Sobranie sochinenij v 8 tomah. T.3. 1962. S.31.

Blok A. In uncertain unsteady flight. Collected works in 8 volumes, Vol. 3, 1962. p. 197.

Brusov V. K stalnym ptitsam. Izbrannoe. Moskva. 1983. S.242.

Briusov V. To steel birds. Favourites. Moscow, 1983. p. 242.

Briusov V. On flights. Favourites. Moscow, 1983. p. 133-134.

Brusov V. Na poletah. Izbrannoe. Moskva. 1983. S.133-134.

Briusov V. Storm of the sky. Collection works in7 volumes, Vol. 3, Moscow, 1974. p. 650.

Brusov V. Shturm neba. Sobranie sochinenij v 7 tomah. T.3.

Khodasevich V. Aviator. Collect of poems. Moscow. 1992. P. 142-143.

Hodasevich V. Aviatoru. Sobranije stihov. Moskva. 1992. S. 142-143.

Kamensky V. Pilots swells. Poetry and prose of the Golden Age of aircraft, Moscow, 2006. P. 83.

Kamenskij V. Ljotchiki-molodchiki. Poezija I proza zolotogo veka aviatsii. Moskva. 2006. S.83.

Kataev V. Fly. Poetry and prose of the Golden Age of aircraft, Moscow, 2006. P.46. 
Kataev V. Letjat. Poezija I proza zolotogo veka aviatsii. Moskva. 2006. S.46.

Kassirer E. Metaphor force. of metaphor. Collection, Moscow, 1990. P. 33.

Kassrer E. Sila metaphora. Teorija metaphory. Sbornik. Moskva. 1990. S.33.

Maiakovski V. You give the motor. Complete works in 12 volumes, Vol. 2, 1939. P. 59.

Mayakovskij V. Dajosh motor. Polnoe sobranije sobranije sochinenij v 12 tomah. T.2. 1939. S.59.

Maiakovsky V. Unless both of your shovels don't itch? Complete works in 12 volumes, Vol. 2, 1939. P. 436.

Mayakovskij V. Razve u vas ne cheshutsa obe lopatki?. Polnoe sobranije sobranije sochinenij v 12 tomah. T.2. 1939. S.436.

Maiakovski V. Moscow-Konigsberg. Complete works in 13 volumes, Vol. 5, 1959. P. 90.

Mayakovskij V. Moskva-Kenigsberg. Polnoe sobranije sobranije sochinenij v 13 tomah. T.5. 1959. S.90.

Platonov A. Happy Moscow. Moscow. 2010. P. 9 - 110.

Platonov. A. Schastlivaja Moskva. Moskva. 2010. S. 9 - 110.

Styazhkova, L. The type of peoples will remind birds, but « nobody will need parliaments». Perm`s news, 1993, No. 11 (119), available at: www.liter.perm.ru/ess_kamen01

Stjazhkova L. Tip ludej budet napominat ptits, a "v parlamentah nikto ne budet nuzhdaysa". Permskije novosti. №11 (119). 1993. tochka dostupa: www.liter.perm.ru/ess_kamen01

Yakovlev S. Aeroplan. Po Wellsu [Airplane. According to Wells]. Moscow, 1924. 24 p.

Yakovlev S. Aeroplan. Po Wellsu. Moskva. 1924. 24 s. 


\section{Трансформация телесных взаимосвязей авиатора \\ и машины в русской литературе начала XX века}

Т.А. Загидулина

Красноярский государственный педагогический университет

имени В. П. Астафьева

Россия, 660049, Красноярск, ул. А. Лебедевой, 89

Исследование посвящено проблеме трансформаџии телесных взаимосвязей авиатора и машины в русской литературе 10-20-х годов ХХ века. Цель данного исследования сопоставление концептуальных зооморфных, антропоморфных и технических метафор классической и неклассической поэтики. Для анализа взяты тексты 10-20-х годов ХХ века авиационной тематики, выбор текстов обусловлен их репрезентативностью в контексте представленного периода. Автор работы обращает внимание на формирование двух мифов: мифа футуристического, направленного в будущее, где актуализируется слияние человека с машиной, а также уподобление человека механизму, и мифа, направленного в прошлое, где на первый план выходит уподобление машины живому существу. Миф, направленный в прошлое, релевантен для текстов классической поэтики (А. Блок, А. Куприн, Л. Андреев и др.). Он полностью вписывается в досоветскую христианскую картину мира с приматом духа над разумом, а также с христианскими представлениями о структуре пространства (сакральньй верх - профанный низ). Миф футуристический, разработанный В. Маяковским, В. Ходасевичем, В. Каменским и др., стремится к десакрализации пространства неба, выводя на первый план идею слияния человека с машиной и даже идею замешения человека машиной.

Таким образом, можно говорить о двух мифологиях как о двух картинах мира, проявляюшихся в литературе и культуре в такой принципиально важный, переломный для русской культуры момент, как первые два десятилетия $Х Х$ века.

Ключевые слова: миф, зооморфная метафора, антропоморфная метафора, телесность, советская литература, сочреализм.

Научная специальность: 10.00 .00 - филологические науки. 